\title{
IDENTIFYING ADVANTAGES AND DISADVANTAGES OF VARIABLE RATE IRRIGATION: AN UPDATED REVIEW
}

\author{
S. A. O’Shaughnessy, S. R. Evett, P. D. Colaizzi, M. A. Andrade, \\ T. H. Marek, D. M. Heeren, F. R. Lamm, J. L. LaRue
}

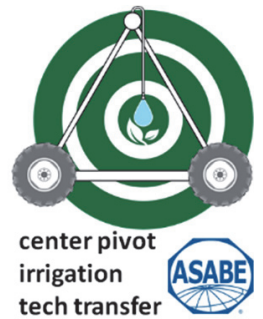

Collection

\begin{abstract}
Variable rate irrigation (VRI) sprinklers on mechanical move irrigation systems (center pivot or lateral move) have been commercially available since 2004. Although the number of VRI, zone or individual sprinkler, systems adopted to date is lower than expected there is a continued interest to harness this technology, especially when climate variability, regulatory nutrient management, water conservation policies, and declining water for agriculture compound the challenges involved for irrigated crop production. This article reviews the potential advantages and potential disadvantages of VRI technology for moving sprinklers, provides updated examples on such aspects, suggests a protocol for designing and implementing VRI technology and reports on the recent advancements. The advantages of VRI technology are demonstrated in the areas of agronomic improvement, greater economic returns, environmental protection and risk management, while the main drawbacks to VRI technology include the complexity to successfully implement the technology and the lack of evidence that it assures better performance in net profit or water savings. Although advances have been made in VRI technologies, its penetration into the market will continue to depend on tangible and perceived benefits by producers.
\end{abstract}

Keywords. Center pivots, Crop water use efficiency, Irrigation, Management zones, Moving sprinkler irrigation systems, Precision irrigation, Sensor based systems.

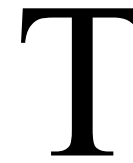
The increasing pressure on our water resources pushes us to manage our water more precisely. With a growing demand for food production, variable rate irrigation (VRI) is a technology that may improve irrigation water productivity (yield produced per unit of water diverted for irrigation), or when combined with sensor feedback, improve crop water productivity (CWPwork is licensed under a Creative Commons AttributionNonCommercial-NoDerivatives 4.0 International License https://creative commons.org/licenses/by-nc-nd/4.0/

Submitted for review in September 2018 as manuscript number NRES 13128; approved for publication as part of the Center-Pivot Irrigation Tech Transfer Collection by the Natural Resources \& Environmental Systems Community of ASABE in March 2019.

Mention of company or trade names is for description only and does not imply endorsement by the USDA. The USDA is an equal opportunity provider and employer.

The authors are Susan A. O'Shaughnessy, Research Agricultural Engineer, Steve R. Evett, Research Soil Scientist, Paul D. Colaizzi, Research Agricultural Engineer, Manuel A. Andrade, ORISE Fellow, USDA-ARS, Soil and Water Management Research Unit, Bushland, Texas; Thomas H. Marek, Senior Research Engineer, Texas A\&M AgriLife Research, Amarillo, Texas; Derek M. Heeren, Associate Professor, Department of Biological and Systems Engineering, University of Nebraska, Lincoln, Nebraska; Freddie R. Lamm, Professor and Research Irrigation Engineer, KSU Northwest Research Extension Center, Colby, Kansas; and Jacob L. LaRue, Research and Development, Valmont Irrigation, Valley, Nebraska. Corresponding author: Susan A. O’Shaughnessy, 300 Simmons Road, Unit 10, Bushland, TX 79012; phone: 806-356-5770; e-mail: Susan.OShaughnessy@ars.usda.gov.
} 
challenges of unpredictable precipitation patterns, more frequent drought episodes, pressure to implement best management practices (BMPs) for sustainable nutrient and water management, and declining water resources for crop production. Today's producers have a greater understanding of the relationship between resource conservation and crop profitability and are more likely to adopt BMPs (Adusumilli and Wang, 2018). Extension training, environmental awareness and positive stewardship attitudes have a helpful influence on adoption of BMPS (Baumgart-Getz et al., 2012; Floress et al., 2017).

While VRI technology may not be economically advantageous for all sprinkler irrigated fields, the majority (more than $56 \%$ ) of irrigated acres in the United States is by moving sprinkler systems (USDA-NASS, 2013). In intensively irrigated areas such as the Texas High Plains, center pivots account for $85 \%$ of the irrigation systems. The application efficiency of these pressurized irrigation systems is greater compared with gravity flow systems (Howell, 2002). In some cases, further improvements in water conservation could be achieved with VRI technology, especially in the case where water can be withheld from non-arable areas within a field (Sadler et al., 2005). Improvements in CWP can be achieved by incorporating irrigation scheduling with VRI technology; specific examples are given later in the text. Focusing efforts on technologies for improving sprinkler irrigation scheduling using VRI systems could have far-reaching positive effects because crop water needs vary spatially and temporally throughout an irrigation season in many fields (Padhi et al., 2012; Cohen et al., 2017). The variability could result from physical differences in soil texture, salinity and topography to unintentional mismanagement such as irregular planting rates and non-uniform fertilizer and herbicide applications to incidences of disease and pest infestation. Combining irrigation scheduling with VRI technology could optimize irrigation as an input (Sadler et al., 2005) and help prevent over-watering some areas and underwatering other areas within a field (Evett et al., 2014a).

In examining the advantages to VRI technology, it is also important to consider any possible disadvantages. In Evans et al. (2013), the authors focused on potential barriers to low adoption of site-specific (SS) VRI systems and identified short- and long-term research needs required to facilitate the implementation of VRI technology. The barriers that they identified included lack of demonstration that the technology provides an economic advantage or reduces negative environmental impacts, insufficient evidence to support claims of expected benefits, and the full implementation of precision irrigation (advanced SS-VRI). During the past five years, research in VRI technology has demonstrated advantages especially in the economic, environmental and agronomic areas. Furthermore, the private and public sectors have accomplished most short-term needs identified by Evans et al. (2013). Progress in long-term needs (also identified in Evans et al., 2013), such as demonstrating that VRI technology provides improved water management or increased net returns, and advanced sensor-driven decision support continues today. This article identifies advantages and disadvantages as well as potential advantages and disadvantages of VRI technology for moving sprinklers, provides current examples on such aspects, suggests a protocol for implementing the technology and reports on recent advancements. Dissemination of updated information is important as it serves to educate other researchers, producers, and policy makers involved in water resources. Likewise, the development of a protocol to implement VRI technology is crucial and not explicitly stated in other publications.

\section{AdVANTAgES AND Disadvantages OF VRI}

VRI technology will result in varying degrees of beneficial and non-beneficial outcomes for each field (Pokhrel et al., 2018) because the type and amount of variability is different in each field, and the return on investment depends on a number of factors including crop type, useful life of the equipment, cost of water, and the cost to pump the water (Marek et al., 2001; Almas et al., 2003). Since some fields benefit from VRI and some fields do not, more studies are needed at the landscape level to quantify the proportion that will be amenable to this technology. Most current VRI studies are focused on the field-scale level. Conversely, a producer may or may not encounter one or any of the disadvantages associated with VRI technology. Therefore it is appropriate to qualify advantages and disadvantages as potential. Before reviewing advantages and disadvantages of VRI technology, it is important to identify the different methods to achieve variable watering rates with moving irrigation systems and to recognize that multiple resources for VRI management exist. The methods for VRI include: 1) speed or sector control, where the water application rate is varied in the direction of the moving sprinkler by varying its travel speed, and 2) zone control, which allows watering application rates to be varied along the lateral pipeline as well as in the direction of sprinkler movement. Zone control has several variants; examples include banks or groups of sprinklers fed by a manifold, where flow is varied at the manifold level, or sprinklers are fed directly by conventional outlets and/or drops, where flow is controlled at the sprinkler level. In addition, flow variation can be in discrete steps (i.e., combinations of valves that are either on or off) or continuous. The five major sprinkler irrigation companies (Valmont, Zimmatic, T-L, Reinke, and Pierce), provide some type of VRI management for moving sprinklers (Kranz et al., 2012a), as do a few third-party companies (LaRue, 2014). A summary of advantages and disadvantages of VRI technology are listed by main categories (table 1). The items listed under each category are not all encompassing and could be listed under more than one category.

\section{AdVantages}

While VRI is not likely to reduce the consumptive use of water (i.e., evapotranspiration) on farms where water is not limited, VRI may reduce pumping for irrigation, resulting in a reduction in greenhouse gas emissions (Trost et al., 2013) and energy savings (Hedley et al., 2009) and reduced runoff and deep percolation of water below the root zone (Daccache et al., 2015; González Perea et al., 2018a). The approach of matching watering rates with variable available water holding capacities of areas within a field could lead to water savings compared with uniformly irrigating the entire field. In a two-year field study (2014-2015), Sui and Yan (2017) 
Table 1. Main categories and examples of potential advantages and potential disadvantages identified with VRI technology.

\begin{tabular}{|c|c|}
\hline Advantages & Disadvantages \\
\hline $\begin{array}{cl}\text { Economic } & \\
- & \text { Reduce water wastage } \\
\text { - } & \text { Reduce pumping costs } \\
\text { - } & \text { Improve water conservation } \\
\end{array}$ & $\begin{array}{l}\text { High upfront costs for VRI zone control } \\
\text { - Increased payback period } \\
\text { - } \quad \text { Inability to finance improvements } \\
\text { - } \quad \text { Benefits are difficult to quantify in financial terms }\end{array}$ \\
\hline $\begin{array}{l}\text { Environmental } \\
\text { - } \quad \text { Gain of land use for dairy or cattle waste disposal } \\
\text { - } \quad \text { Reduce leaching below the rootzone } \\
\text { - } \quad \text { Reduce runoff and non-point source pollution }\end{array}$ & $\begin{array}{l}\text { Additive factors increase costs } \\
\text { - } \quad \text { Variable frequency drives must be considered } \\
\text { - } \quad \text { ECa field or topography mapping } \\
\text { Within-field or on-sprinkler sensors for precision irrigation, data acquisi- } \\
\text { tion from aerial imagery }\end{array}$ \\
\hline $\begin{array}{ll}\text { Agronomic } \\
\text { - } & \text { Reduce inputs of water, fertilizer, chemicals } \\
\text { - } & \text { Improve whole-field crop water productivity } \\
\text { - } & \text { Provide a means to implement precision irrigation }\end{array}$ & $\begin{array}{l}\text { Additional hardware } \\
\text { - Increases labor for troubleshooting and repair } \\
\text { - } \quad \text { Limited alarm systems to alert malfunctions } \\
\text { - Increases time invested in maintenance }\end{array}$ \\
\hline $\begin{array}{l}\text { Risk management } \\
\text { - } \quad \text { Address variable or limited water supplies } \\
\text { - } \quad \text { Sustain irrigated agriculture }\end{array}$ & $\begin{array}{l}\text { Complexity } \\
\text { - Steep initial learning curve and increase in time investment to implement } \\
\text { - } \quad \text { Matching watering rates to variable spatiotemporal crop water needs } \\
\text { - Risk of reduction in yield or crop quality }\end{array}$ \\
\hline
\end{tabular}

demonstrated a savings of $25 \%$ irrigation water and a yield increase of $2.8 \%$ in soybean using VRI management as compared to uniform rate irrigation management (URI). Appropriate timing and watering amounts to specific areas within a field could reduce water wastage and energy costs as well. Irrigation scheduling can be improved through software and information from university, state sponsored, or private agrometeorological services (e.g., Arkansas Irrigation Scheduler (AIS), North Dakota Agricultural Weather and KanSched2), or through plant and soil water sensing feedback (Evett et al., 2014b). As an example, Vories et al. (2017) used the AIS software to calculate a soil water balance and irrigated when pre-established soil water depletion thresholds were reached. Irrigation amounts were based on established values of 10 or $15 \mathrm{~mm}$ for delineated MZs and applied with a VRI center pivot system. The Texas State Water report recognizes VRI as a means to reduce irrigation water demand (Texas Water Report, 2014) and viewed as a potential method to overcome decreasing water allocations and limited water supplies.

\section{Economic}

Hedley et al. (2009) reported water savings on the order of $9 \%$ to $29 \%$ in irrigation simulations by either matching irrigation applications to available water holding capacity of delineated management zones (MZs) or by reducing excessive drainage using VRI management. Soil water sensors were strategically placed in the MZs, which were delineated by soil texture. Dennis et al. (2010) showed that applying differential irrigations to areas within a field characterized by unique available water holding capacity resulted in a seasonal water savings ranging from 0.33 to $1.0 \mathrm{ML} / \mathrm{ha}$ on two separate pastoral farms. Soil water sensors were located in representative areas of soil water holding capacity in each type of MZ and were used for irrigation timing. Sui and Yan (2017) also used VRI technology to apply irrigation to meet the temporal and spatial variability in soil and plant characteristics within a field and compared irrigation amounts with uniform rate irrigation (URI). The field was divided into four sectors; two sectors were irrigated uniformly and two were subdivided into MZs based on soil electrical conductivity (EC) maps. They installed a set of three soil water sensors in each type of $\mathrm{MZ}$ to monitor soil water content levels and triggered irrigations when the soil water content was depleted to $74 \%$ of field capacity. The VRI technology used $25 \%$ less water compared with the URI.

An analysis of 49,224 center-pivot-irrigated fields in Nebraska estimated the potential pumping reduction from VRI by accounting for spatial soil properties. Results indicated that pumping reductions would exceed $5.1 \mathrm{~cm} / \mathrm{yr}$ for $2 \%$ of the fields and would exceed $2.5 \mathrm{~cm} / \mathrm{yr}$ for $13 \%$ of the fields (Lo et al., 2016). Adoption of zone control VRI for better management of stored soil water was determined to be most economical for fields where the pumpage reduction using VRI is large and pumping costs are above normal. For the high-water cost scenario, the present value (calculated for a payback period of 10 years) of the pumping reduction exceeded $\$ 10,000$ on $10 \%$ of the fields and $\$ 27,500$ on only $0.4 \%$ of the fields (Lo et al., 2016).

\section{Environmental}

An environmental benefit of a system that controls water application spatially, is the prevention of deep percolation and runoff, which can lead to excessive nutrient loss. Over-watering often results in pushing water below the rootzone and leaching nitrogen and other chemicals into groundwater. Irrigation management for crop production is interconnected with nutrient management. Regional total nitrogen inputs to agriculture have increased over time, while nitrogen use efficiency has decreased in the Eastern Uplands, Northern Great Plains and Southern Seaboard regions of the U.S. (Swaney et al., 2018). State agencies are encouraging BMPs to reduce agricultural nonpoint source pollution, minimize eutrophication and protect water quality. As an example, Florida is implementing strategies to improve water quality by reducing pollutant loads. The plan includes BMPs for agriculture and is undertaking projects that include VRI technology and soil water probes to reduce nitrogen leaching from farmland (Suwannee River Basin SWIM Plan, 2017). Failure to successfully deter nitrate contamination would require water treatment of potable water supplies. Reducing pumpage with VRI may lower on-farm fertilizer costs (due to less nitrogen loss through denitrification and leaching) and reduce the need to remediate public drinking water supplies.

A second major pathway of excessive water application is runoff, which can lead to soil erosion and non-point source 
pollution due to nutrient movement, especially nitrogen and phosphorous. Producers must choose BMPs that optimize nutrient efficiency and protect water quality. Sigua et al. (2017) demonstrated that a VRI system using Irrigator Pro for corn as an irrigation scheduling method resulted in lower concentrations of pore water nitrate and phosphate leached from the plots that were delineated by soil texture. Irrigated acreage has shifted from the western states to the Delta and Southeast (except for Florida) due to increases in commodity prices and yields and increasing water availability challenges in the West (Schaible and Aillery, 2017). Many growers who have traditionally relied on rainfed crop production now use supplemental irrigation to maintain crop yields during periods of within-season drought and unpredictable rainfall patterns. If soil storage is exceeded, large precipitation events will leach soluble nutrients stored in the rootzone. These growers are challenged not only to preserve profitable yields, but to adequately manage irrigations to help maintain water quality of nearby surface waters or groundwater with shallow water tables. Examples where VRI can help to mitigate nutrient transport across irrigated acreage were reported in McDowell et al. (2011) and McDowell (2017) where New Zealand farmers used VRI to help mitigate the fate and transport of $\mathrm{N}$ and $\mathrm{P}$ to surface water.

Using VRI over slopes and valleys within a field could also help reduce runoff and soil erosion from hilly areas and reduce ponding in the low areas. The reduction of ponding in low lying areas is especially critical in limiting disease and $\mathrm{N}$ leaching in potato fields (Davenport and Hattendorf, 2000). Nelson and Zebarth (in CMDC Potato report, 2016) found that VRI resulted in greater tuber yields than URI on a research field. They also found that VRI produced similar yields on a commercial farm compared to URI, however under VRI the amount of disease was reduced by $50 \%$.

A less discernible advantage of zone control VRI is efficient land application of dairy cattle wastes and swine manure by withholding the effluent over waterways that traverse a field and applying it to as much land as compliantly possible. Often process wastewater from dairies or confined animal feed operations are applied to land as a means for disposal. Typically, liquid manure that contains less than $0.5 \%$ solids can be applied with moving sprinkler systems (Liu et al., 2012). It is critical that wastewater be applied to land in compliance with environmental regulations to prevent discharge to U.S. water bodies and to prevent water pollution from contaminated runoff during rainfall or snowmelt events (US-EPA, 2014). The limitations of land disposal of farm effluent are dependent on favorable climatic and soil moisture conditions, the requirement for greater storage facilities when application conditions are poor, and the concentration of effluent aerosols that can result in odor problems (Bolan et al., 2009). With appropriately designed zone control VRI systems, dairy farmers that apply wastewater to cropped fields can turn off water in sprinkler zones that pass over a waterway yet allow wastewater to continue to be applied to other areas in the field. This practice increases the percent land available for application of wastewater Younker (2018). Hedley (2015) describes a dairy farm effluent (DFE) program involving VRI technology to construct the DFE according to plant needs and nutrient input, while avoiding critical source areas of nutrient loss. The same logic applies to the application of fertilizer or pesticide, which is often accomplished through the moving sprinkler system. With VRI it is also possible to match areas of soil with low available water holding capacity to applications of low watering rates of wastewater to help reduce groundwater contamination and similarly match MZs to nutrient management plans.

\section{Agronomic}

It is easier to economically justify an investment in zone control VRI by improving the overall yield (within the field) rather than reducing pumping (Lo et al., 2016) as discussed earlier. VRI may be used to improve overall yields by preventing over-irrigation and/or under-irrigation. Producers typically schedule irrigation according to the driest areas in a field or install soil water sensors in areas with the lowest available soil water holding capacity to alleviate under-irrigation of any part of the field (Peters et al., 2013 as cited in Daccache et al., 2015). In general, the practice is likely to increase irrigation frequency and may lead to over irrigation of areas with higher soil water holding capacities. Over-irrigation can reduce yields through depletion of oxygen and/or leaching of nutrients out of the root zone. Preventing underirrigation in areas within a field where yield potential is great can also help to optimize water as an input. For typical irrigated crops in the Central Great Plains (i.e., maize and soybeans), maximum yield is achieved by minimizing water stress. Some crops, however, attain maximum yield quantity or quality under mild deficit irrigation, resulting in a narrow range of seasonal irrigation (for each $\mathrm{MZ}$ ) that is required to reach maximum profit as shown by O'Shaughnessy and Evett (2010a) for cotton; this scenario has potential of paying for a zone control VRI system by improving yields (Lo et al., 2016).

An obvious advantage of zone control VRI systems is that water can be withheld over areas of a field that are not arable, such as rock outcroppings, utility roads, or areas that should be avoided to help reduce nutrient loading of waterways and to comply with environmental regulations. The majority of early-adopted zone control center pivots were installed in the eastern United States and were used to help with environmental compliance by withholding water (Evans et al., 2013).

Crop water requirements vary spatially and temporally. The use of VRI as a tool to implement irrigation scheduling spatially and temporally can enable growers to better manage inputs (of water and fertilizer) and meet regulatory water allocations and nutrient management policies. Integrated water management could also lead to positive economic, social (convenience, time-management savings), societal (water planning and conservation) and environmental benefits. Reduced watering amounts can be applied to areas that historically produce marginal yields or to low lying areas that pond under full irrigation. The amount of water to be applied over the low-producing areas will depend on the overall profitability of net returns. Yang et al. (2002) found that profit maps of net returns from sorghum (derived from yield monitor data) were highly variable among and within 10 fields in southern Texas. They determined that the low yields were mainly due to soil properties and partly due to 
lack of irrigation water. Allaire et al. (2014) found that potato tuber yield and plant nitrogen uptake varied spatially due to variability in soil texture, soil water content and soil temperature. Stone and Sadler (2016) used a Bayesian semiparametric model to reanalyze spatial corn yield data and concluded that spatial differences were great enough to be considered in irrigation design and management. These results could aid producers in making critical water management decisions or specifying VRI hardware.

Improving crop water use efficiency (WUE) using deficit irrigation management is a critical consideration for producers in water-limited regions. Irrigated agriculture doubles or triples yields of grain crops and mitigates the risk of total crop failure from drought conditions. The rational decision in the case of limited water supply is to practice enough deficit irrigation to maximize crop water productivity (CWP) and then reduce the planted area to cope with the water supply limitation. Variable rate irrigation technology could enable growers to improve CWP if the appropriate amount of water is only applied where and when needed. Studies by O'Shaughnessy and Evett (2010a). O'Shaughnessy et al. (2012), and O'Shaughnessy et al. (2015) demonstrated that precision irrigation management of sorghum and cotton using canopy temperature sensing for plant feedback resulted in yields and WUE that were similar to sorghum and cotton managed by weekly neutron probe readings for well-irrigated and mild-deficit irrigated treatment plots. Weekly neutron probe readings were used to replenish the soil water profile in the top $1.5 \mathrm{~m}$ to field capacity. Both irrigation scheduling methods were effective in preventing over- and under-irrigation. In the study by Sui and Yan (2017) mentioned previously, it was demonstrated that CWP for soybean and corn was better under VRI than URI in a two-year study in Mississippi. Zhao et al. (2017) and Li et al. (2018) found that practicing VRI using MZs delineated by differences in available water holding capacity resulted in winter wheat and maize crop water productivity that was greater than the overall average values for the field. In this way, VRI could also be used to redistribute irrigation water to areas in a field where yields are greater, but away from areas where yields are consistently low, and water is not the limiting factor. In the latter scenario, low yielding areas could be due to disease and pest infestation, which can cause spatiotemporal reductions in crop water uptake and limit yields if infestation occurs early in the season (Price et al., 2010; Workneh et al., 2017). Low producing areas within a field could also be due to waterlogging as shown by Maestrini and Basso (2018a) for various crops in fields across Arkansas, Kansas and Colorado. In the situation where water is very limited, a producer may benefit from establishing dry zones withholding water from low producing areas of the field. Applying water to the appropriate location, only when needed and where needed could allow farmers to improve economic yields per the amount of total crop water use.

\section{Other Advantages}

Another benefit of VRI technology is its use in phenotyping studies for drought tolerance and in deficit irrigation research. Seed companies often utilize VRI systems to apply differential irrigation amounts to variety trial plots to easily establish different irrigation levels and monitor corresponding crop physiological responses. Randomization of irrigation treatments is easily accomplished with VRI technology with reduced or no additional labor.

Variable rate irrigation technology could also be used to solve various field-specific problems (Heeren et al., 2017). For example, to eliminate over-irrigation in a situation with overlapping pivots (a design-practice that is not encouraged), VRI could be installed on just a few spans of one of the pivots. Zone control VRI on a corner arm could be used to put on a more uniform application depth. In the past, corner arms often have a high level of nonuniformity, however microprocessor-based control equipment linked to the GPS system on the sprinkler have improved uniformity along corner arms due to more accurate position detection, alteration of machine speed and faster communication between system components (Smith, 2012). Also, VRI could be used to allow an irrigation system to continuously utilize full pumping capacity when a corner arm or an end gun would typically require changing flow rates. VRI could be used to reduce the application rate on problematic soils. For example, using zone control VRI, sprinkler travel speed can be maintained but pulsing the water "off" and "on" while the sprinkler travels over soils with high clay content or steep slopes. The lower watering rate will help reduce runoff (Peters and Flury, 2017). Similarly, lowering the water rate by "pulsing" the water during early-season irrigations will be beneficial by reducing soil sealing. Finally, VRI can be used to apply variable rates of fertilizer (i.e., variable rate chemigation), which would be beneficial in applying amounts that more closely match variability in crop nutrient requirements (Lo, 2015). VRI may also be used on center pivots with low flows to minimize the impact of over-watering in the first two spans if properly-sized sprinkler nozzles are not available.

\section{DisadVANTAGES}

Although potential benefits have been identified, the adoption of VRI sprinkler systems continues to be less than expected and is likely due to a combination of issues. Using farm survey data from the 2008 Census of Agriculture Farm and Ranch Irrigation Survey (FRIS), Schaible and Aillery (2012) reported that the cost of irrigation system upgrades was an important limiting factor in irrigation investment decisions. Data from the 2012 FRIS (USDA-NASS, 2013) indicated that $32 \%$ of respondents identified the inability to finance improvements as a barrier to implementing irrigation system improvements, while $13 \%$ believed that improvements would increase management time or cost. Although the surveys did not explicitly specify VRI technology systems, the responses can be extrapolated to include this technology. Producers who are considering whether to invest in VRI technology should carefully consider the potential disadvantages as well as the potential advantages to determine whether VRI is a good fit for their situation. The major issues compared with conventional sprinkler systems are greater capital costs (Evans et al., 2013), a greater level of management (Stone et al., 2016) and maintenance, difficulty in building adequate and optimized prescription maps, substantial time investment required to modify the maps, and limited comprehensive technical support from the industry (Martin 
et al., 2015). While greater upfront capital costs are relevant to zone control VRI, most center pivot systems already have computer control panels that enable speed control VRI. Therefore, it may be that the latter issues are of greater impedance to implementing VRI. The following text expands on the major disadvantages of VRI technology.

\section{Costs}

Higher costs require considerations regarding the ability to finance the technology and the payback period to recover the investment costs. The longer the return on investment, the more speculative the investment (Schaible and Aillery, 2012). Both upfront and additive costs increase the return on investment for this technology and producers may not have the capacity to finance the additional costs. The cost of zone control VRI hardware will vary from manufacturer to manufacturer depending on the type of hardware selected (such as valve choice) and the number of zones equipped. Generally, producers choose not to control the entire moving sprinkler with VRI technology because the upfront cost is high, irrigation is withheld in only some areas in a field, or water management is focused only on the largest parts of the field. Typical costs could range from $\$ 247 \mathrm{ha}^{-1}\left(\$ 100 \mathrm{acre}^{-1}\right)$ at the low end to $\$ 730 \mathrm{ha}^{-1}\left(\$ 365 \mathrm{acre}^{-1}\right)$ at the high end. Although speed control comes at a much lower cost, the system must include a GPS unit and an updated control panel or additional hardware to change the center pivot's travel speed and to start and stop the sprinkler system. Remote communication hardware is often used to operate most VRI sprinkler system technology; although not essential, it provides convenience and savings in time management (Kranz et al., 2012a). In addition, to achieve uniformity of application, the pressure of a VRI sprinkler system should remain relatively constant (Zhu et al., 2002); thus, the use of variable frequency drives (VFDs) should be used to mitigate this concern. The design of the VFD controller must consider the specifications of the existing pump and pump motor. Improper impeller adjustment, impeller wear, or a mismatched motor can result in little to no benefit or increase pumping costs (Henry et al., 2014). Many existing irrigation pumps are not suitable for VFD control and the cost of the pump and controller conversion adds to the total cost of the VRI system. However, without a VFD governing system pressure, there may be a waste of pump energy. The amount of utility costs savings depends on such factors as within-field topographical differences, hours of center pivot operation, and the cost of electricity (Brar et al., 2017). The addition of sensors and sensor network systems for precision irrigation management will also increase the cost of VRI technology. The cost will vary by sensor type, manufacturer and the software necessary to capture and convert the data into usable information for irrigation scheduling.

\section{Maintenance}

In addition to the maintenance required for a conventional sprinkler system (Kranz et al., 2012b; Rogers, 2012), a VRI sprinkler designed for zone control will require maintenance of additional hydraulic, electrical and mechanical parts. The maintenance will depend on the VRI hardware design. As an example, over time, the diaphragm of a hydraulic valve which pulses "on" and "off" can weaken or the orifices within the valve can become clogged with minerals and debris. Both problems often result in water leaking from the valve due to the inability of the diaphragm to fully close. Partial clogging and incomplete operation of the hydraulic valves can result in the reduction of the prescribed watering rate. Similarly, minerals in the water and debris can cause clogging at the orifices of an electronic solenoid valve, preventing the closure or pulsing action of a sprinkler bank. The malfunction of a solid-state relay to actuate a solenoid valve could cause a sprinkler bank to fail by preventing water from being applied to a specific management zone. Currently there are limited methods to detect these issues and notify end users. In some manufacturer's designs, and for most methods of precision irrigation, wireless sensor networks are an integral part of VRI technology. Wireless communications are advocated to eliminate interference with farm operations. However, maintenance is required in managing and troubleshooting these networks (Vellidis et al., 2008; O'Shaughnessy and Evett, 2010b). Producers lack adequate assistance to develop and adopt better approaches to irrigation scheduling or environmental sustainability using plant or soil water sensors even though they are commercially available (Levidow et al., 2014).

\section{Complexity}

Building prescription maps for decision support can be tedious and time consuming. The software to build prescription maps and user interfaces for decision support for VRI management lag mature engineering technology. The practice of VRI requires that each field be divided into MZs (Khosla et al., 2008). The delineation of MZs may best be accomplished by the importation of GIS-based resources such as from unmanned aerial vehicles (UAVs) or aerial imagery (Khot et al., 2016; Hoffman et al., 2016), apparent electrical conductivity $\left(\mathrm{EC}_{\mathrm{a}}\right)$, soil texture, topographical, or yield maps (Zhang et al., 2002; Camilli et al., 2007). Although tools have been and are currently being released from several manufacturers to automate the process, the fusion of information from several GIS layers is not straightforward (Moral et al., 2010; Gili et al., 2017). Time investment in building prescription maps is compounded by the need to change prescription maps frequently throughout the irrigation season. Dynamic prescription maps are necessary because soil water content varies not only spatially but temporally even in leveled fields (Longchamps et al., 2015), and crop water needs are variable throughout the season due to differences in available soil water holding capacity (Zhao et al., 2017), and changes due to pest infestation or disease (Price et al., 2010; Workneh et al., 2017). Other studies propose that delineation of MZs be dynamic or at least reconsidered on a seasonal basis due to climate variability (Schepers et al., 2004; Haghverdi et al., 2015).

In addition to cost, the use of sensors for precision irrigation management with VRI also increases the complexity of the technology. Complexity increases in terms of choosing the appropriate type of sensor, the number of sensors, the location of sensors and how to use the data acquired from the sensors. If in-situ soil water sensors are to be used, there are various soil water sensing technologies. All measure a surrogate soil property (Or and Wrath 2002; Schwartz and 
Evett, 2016); however, all are influenced to some degree by soil bulk electrical conductivity, temperature and salinity (Evett et al., 2011; Kargas and Soulis, 2019) making irrigation scheduling less than straightforward. Also, cumulative water infiltration can be variable and differ with respect to tillage methods (Schwartz et al., 2011). Hedley and Yule (2009) suggested a sensor or set of sensors be located in each MZ; they used an electromagnetic time domain transmissometer (TDT) that was $3 \mathrm{~m}$ long and placed diagonally in a trench. Sui and Yan (2017) installed three soil water sensors (EC-5, Decagon Devices, Pullman, Wash.) in each MZ irrigated using VRI. The soil water sensors were fixed at depths of 15,30 , and $61 \mathrm{~cm}$ and a weight (dependent on rooting depth of the particular crop) was assigned to each reading when calculating soil water content to a depth of $61 \mathrm{~cm}$.

Climate variability introduces complexity to VRI management in that it requires decision support be responsive to current weather and crop conditions (Smith et al., 2010). Decision support to address temporal variability requires sensor feedback at a relatively high resolution $(>2 \times /$ week). Currently, proximal sensor and aerial image feedback (e.g., soil water and plant sensors) provide information at this resolution. Wireless plant and soil water sensor networks system components and unmanned aerial vehicles (UAVs) are also available on the market, but there are costs associated to integrate the sensors and data output with VRI technology. Uncomplicated graphical user interfaces (GUIs) and mobile applications (Migliaccio et al., 2016; Vellidis et al., 2016) have been developed to make the decision support information easy to access and understandable. Evans et al. (2013) declared a long-term need to be advanced decision support systems. Currently, more robust algorithms are in development to manage the large amounts of data from various platforms and provide decision support while delivering the information within a user-friendly software environment. Decision support tools that aid in the determination and optimization of these issues (Andrade et al., 2015, 2016, 2017; Liakos et al., 2017; Yang et al., 2017; Barker et al., 2018) are under development but have not been commercialized to date. They are presented later in the article.

\section{Other Disadvantages}

Other disadvantages of VRI technology may be encountered when the irrigation water is of poor quality or the size of the cropped field is large requiring substantial time for the moving sprinkler to complete a rotation. When irrigating with moderately saline water, VRI management could lead to insufficient leaching of salts, which could threaten the sustainability of irrigated crop production (Smith et al., 2010). Crops that are typically irrigated with center pivot systems that have minimal tolerance to salinity include corn, alfalfa and sorghum and those with a greater tolerance include barley, cotton and wheat (Rhoades et al., 1992). In the case of large-sized fields, it is possible that VRI management could lead to unintentional yield reductions especially if there is a wide range of available water holding capacity across different MZs. In such cases, the VRI sprinkler system may not be able to travel across the field in time to deliver water to an area with moderately- or severely-water stressed plants.
Crop modeling integrated with VRI technology could provide appropriate decision support to a producer by simulating and developing irrigation control strategies (McCarthy et al., 2010; McCarthy et al., 2014). Currently, decision criteria for triage of target areas to determine whether a target area needs immediate attention or should be given less priority, are lacking. Crop modeling integrated with VRI technology has been used to assess spatial and temporal impacts of VRI compared with URI. Modelling approaches provide a simulated evaluation of agronomic and economic outcomes of the two management methods for different crops (Haghverdi et al., 2015, 2016; González Perea et al., 2018a). McCarthy and Hancock (2013) and Andrade et al. (2018) demonstrated the plausibility of using artificial intelligence and historical data to overcome data gaps. This technology would be useful in situations where it is infeasible to scale up sensor networks for adequate characterization of spatiotemporal variability or in the case of malfunctioning sensors.

Another potential disadvantage to implementing VRI technology is the attitude of the owner/operator. Evans et al. (2013) stated that future decision support must consider the philosophy of the owner/operator relative to methods used to assess soil water content, plant growth stages and determine when a crop requires irrigation. This view was summarized by Greiner and Gregg (2011) who found that philosophies serve as a lens through which farmers evaluate options and justify decisions when they assessed reasons for farmers' motivation to adopt new or additional irrigation conservation activities. In some cases, producers' decisions are not based on information or a prescribed need, but rather are made to avoid risk (Tey and Brindal, 2012). Overcoming traditional methods of irrigation management by adoption of unconventional or new technologies presents a challenge.

\section{Advances}

In addition to long-term needs, Evans et al. (2013) also list six short-term needs and tools for continued commercial development to sustain adoption of site-specific VRI. These include equipment requirements, tools for defining MZs, software to write basic prescriptions, optimal placement of sensors, decision support, technical assistance and educating funding organizations. Some of these needs, technical assistance training, education, and reliable equipment are fixed factors (Tey and Brindal, 2012), meaning that they must always be addressed when offering advanced technologies. In the case of equipment needs, there is progress in the example that the private sector is now providing producers with information on VFDs for VRI applications and in some cases irrigation companies have partnered with original equipment manufacturers to provide packaged solutions. Another factor that already has been addressed by sprinkler irrigation manufacturers that offer VRI technology is the provision for software tools to build basic prescription maps. However, as discussed above, basic prescription maps are generally not adequate to address variability throughout an irrigation season. To address this, some manufacturers have gone beyond basic prescription map building and now facilitate partner- 
ships between producers and a third-party company with expertise on agronomics, soil properties and prescription map building. Current advances are addressing some short-term gaps concerning the limited adoption of VRI technology. These advances have been made by industry members and researchers. For example, Abts and Emanuel (2014) patented a method of optimizing water applications of a center pivot system based on management zones with the highest yield potentials. Software to automatically delineate MZs and tools to determine how to best locate sensors for precision irrigation management are under development (LaRue, 2018). Artificial intelligence has been used for decision support in water management (González Perea et al., 2018b) and is becoming more prevalent in irrigation decision-making (Gu et al., 2017).

As with most businesses, perceived profitability (Tey and Brindal, 2012), cost considerations, and the return on investment (ROI) are of importance to producers when considering PA technologies (Pierpaoli et al., 2013). One opportunity to defray upfront costs is by seeking partial support from federal or state agencies, or developing public-private partnerships with universities, NRCS or ARS laboratories. In some states, incentives were provided for the installation of VRI hardware (Milton et al., 2006). For example, funds from the NRCS EQIP program were administered by the Flint River Soil and Water Conservation District. In Texas, the Water Development Board offers funding for selected research projects on advanced technologies for irrigation management and generally supports the demonstration of promising and adaptive water conservation technologies. The Texas Alliance for Water Conservation, a partnership between area producers, data collection technologies, universities, industries, and government agencies has engaged producers in VRI field research to practice reduction in water losses. Regional Water Management Districts offer education and cost assistance to adopt advanced irrigation scheduling using reference ET data and crop growth stages, and the use of soil water sensors for improved irrigation management. Kansas has Water Technology Farms (https://kwo.ks.gov/projects/water-technology-farms) that enable the demonstration of new technologies and irrigation management strategies on center pivot fields located in different areas of the state. These farms serve not only to test new technologies but to illustrate and educate producers as to their use. Miller et al. (2017) warns that policymakers must be aware of the slow rate of adoption of PA technologies and allow programs to be available for a long period to achieve desired adoption rates.

From an adoption perspective, a grower should demonstrate a commitment to good irrigation scheduling with URI before committing to the increased complexities of irrigation scheduling with VRI. Research has shown that even irrigators with marginal capacity center irrigation systems should use science-based irrigation scheduling (Lamm and Rogers, 2015). In a similar way, a producer could transition to speed control VRI first before deciding whether to invest in zone control VRI. Conceptually, speed control may be easier to understand. The advantages of speed control VRI compared with zone control VRI are that upfront costs are less, resulting in a shorter period for return on investment compared with zone control. Maintenance is no different from conventional systems and will be less than zone control VRI systems which have more mechanical hardware. Speed control VRI will be useful in managing multiple crops that are planted in sectors under a center pivot field when farmers want to diversify their crop portfolio. The operation of the speed control variable rate system will be realized with a minimal learning curve. Speed control VRI can also help producers overcome soil infiltration problems and yet ensure adequate water application by moving the sprinkler back and forth over the problem area (windshield-wiper pattern) to reduce runoff and allow time for the applied water to infiltrate (Peters and Flury, 2017). Speed control is also practiced where producers are limited in well capacity (a common situation throughout the Ogallala Aquifer region) and use multiple crops in a given year or fallow part of the circle due to irrigation capacity constraints. Speed control VRI can also be used to manage some of the spatial variability in soil properties (Miller et al., 2018). It may be prudent to experiment with speed control VRI to investigate if the producer's goals can be obtained before investing in zone control VRI. While upfront costs for speed control are less than zone control, zone control VRI technology offers greater flexibility and resolution in irrigation management (fig. 1).

Critics of VRI systems cite the lack of demonstrated costeffectiveness of benefits as a disadvantage. The challenge in demonstrating water savings, improved water-use efficiency and yields is that side-by-side comparisons between fields are difficult since fields are inherently different from one another and even MZs of the same type within a field can be inherently different from one another. It is also problematic to quantify benefits such as time savings, compliance with EPA regulations, prevention of deep percolation and nitrogen leaching, and mitigation of soil erosion. Hedley et al. (2009) asserted that reporting differences in energy use, ease of compliance with regulations, observable environmental management, and increased crop water use efficiency may help demonstrate cost-effectiveness over uniform rate irrigation. Another governing factor of economics with VRI is that of crop selection. The ROI is directly impacted by crop selection, for example relatively low commodity prices for cereal grains do not provide as good an adoption opportunity as higher valued crops such as vegetables or fruits. Beta testing with other scientists managing different crops in different climates and performing field trials with producers will help evaluate VRI system performance (O'Shaughnessy et al., 2018). In the past five years, there has been minimal forward movement in explicitly demonstrating the cost effectiveness of the technology or demonstrating conditions under which VRI assures greater performance in net profitability or water savings. Schimmelpfennig (2016) considers that the cost of precision agriculture (PA) equipment includes installation charges, and the time and effort spent learning how to use and maintain the technologies. However, he warns that because these costs are not recoverable, producers have a higher expectation on return when adopting PA technologies. The public and private sectors share the responsibility to demonstrate tangible returns in research and on-farm trials. 


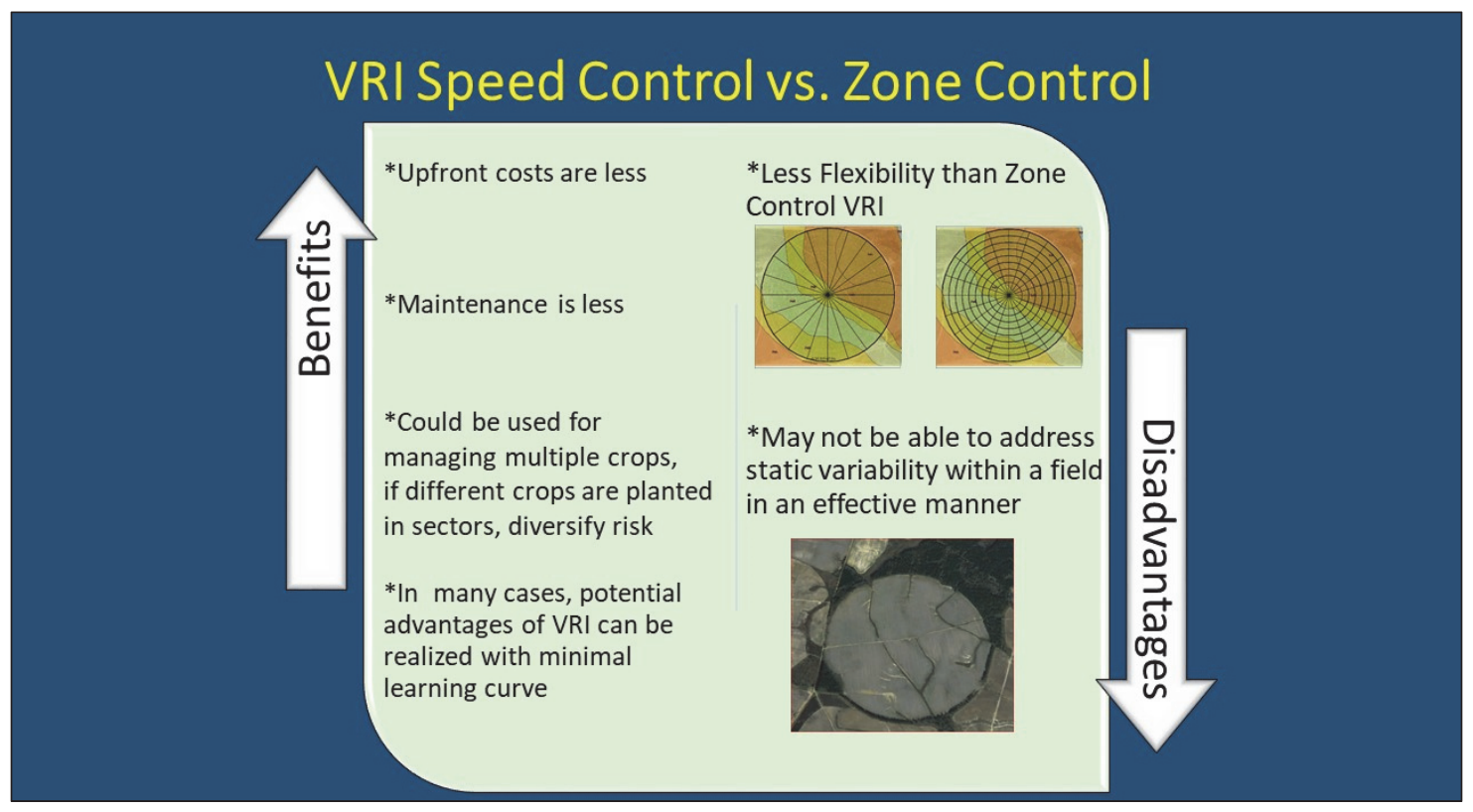

Figure 1. Advantages and disadvantages of variable rate irrigation speed control as compared to zone control.

Recent progress had been made in using data acquired from remote sensing to develop decision support. Field implementation of VRI prescription maps demonstrated that effective management of VRI will likely require a combination of both remote sensing and soil water monitoring (Barker et al., 2017, 2018) to detect dynamic variable crop water needs spatially and temporally. The addition of sensors and sensor feedback adds to the complexity of VRI technology. To overcome these complexities, software programs that integrate sensor networks and sensor feedback with VRI hardware to automatically provide robust decision support for irrigation scheduling are in development (Andrade et al., 2017; Liakos et al., 2017; Sun et al., 2017; Yang et al., 2017). As trivial as it may seem, overcoming the complexity involved with managing a VRI system could be eased by formatting any new software interfaces in a manner that is similar to old interfaces familiar to producers. Software interfaces based on a GIS framework provide easy-to-understand and easy-to visualize recommendations for irrigation scheduling (Andrade et al., 2016).

Whether a producer is considering speed control or zone control VRI technology, the long-time paradigm of applying water uniformly across a field is disrupted. Choosing the appropriate options requires preliminary work between the irrigation dealer and the producer to identify the producer's goals in using VRI technology and explore associated economic advantages and costs. Options in addition to the use of speed control versus zone control, include the number of control zones to add, the width of the control zones and how best to divide the field into MZs. Hands-on demonstrations after installation of the VRI hardware and software, and timely technical support in the field once the equipment is installed and when the producer has questions are critical to customer satisfaction and will help to overcome the learning curve. This requires training commercial dealers and consulting support personnel.
After consideration of the advantages and disadvantages of VRI technology, a protocol for designing the VRI technology should be followed to develop a system customized for a specific field. The following steps are proposed:

1. Develop a protocol for designing a VRI sprinkler system Divide the field into homogeneous areas or MZs. These areas do not have to be contiguous.

One source of soil information is the SSURGO database collected by the National Cooperative Soil Survey over the past century. Software that overlays SSURGO information in the form of maps over a satellite image can be used to help delineate MZs as demonstrated in Andrade et al. (2015).

Another option is to delineate zones based on soil texture using apparent electrical conductivity $\left(\mathrm{EC}_{\mathrm{a}}\right)$ maps (Hedley and Yule 2009; Hedley et al., 2009; Zhao et al., 2017) or other hydrogeophysical datasets (Finkenbiner et al., 2018). However, caution must be exercised to determine whether variabilities indicated by $\mathrm{EC}_{\mathrm{a}}$ maps are due to soil texture, topography, or other differences (Sudduth et al., 2001). Therefore, it is prudent to combine information from $\mathrm{EC}_{\mathrm{a}}$ and topographical maps to delineate MZs (de Lara et al., 2017; Lo et al., 2017; Yari et al., 2017b). Electrical conductivity sensor sleds are relatively economical (Adamchuk et al., 2004; Brevik et al., 2006), with the Veris and the Dual EM EC $_{a}$ EM38 (LaRue 2014) being the most popular. The appropriate times to perform the study are prior to planting in a prepared field or after harvest (Hawkins et al., 2017).

A third source of useful information is biomass or yield data (Maestrini and Basso, 2018b). Haghverdi et al. (2015) determined that soil available water content was the primary attribute to delineating MZs, while satellite imagery, and $\mathrm{EC}_{\mathrm{a}}$ and yield maps provided helpful ancillary data. Li et al. (2018) and Bellvert et al. (2012) report that yield information combined with soil EC worked best to delineate MZs. Recent development of UAV based data acquisition technologies may also provide information regarding this data need (von Bueren et al., 2014; Cahn and Johnson, 2017). 
2. Address variable plant water status during the growing season within each MZ using soil water and/or groundbased plant sensing feedback or data from remote sensing platforms.

3. Establish fundamental irrigation management approaches when applying variable watering rates (table 2):

4. Recognize that plant available water within the established MZs varies constantly as water is depleted and replenished, and as roots lengthen and develop. Furthermore, the plant available water threshold for the onset of water stress varies with atmospheric demand and other biotic and abiotic stresses. Updated prescription maps need to be formulated frequently within the irrigation season and uploaded to the moving irrigation control panel. Use plant, soil water sensors or a combination of proximal sensors and remote sensing to monitor and detect plant water stress and/or soil water depletion.

a. Plant temperature sensing (e.g., infrared thermometers)

b. Soil water sensing- choices are to:

i. Locate a soil water sensing node in each type of MZ. Each node should be deployed in a representative area within the $\mathrm{MZ}$ and contain multiple sensors installed at depths to include most of the crop's rootzone (Hedley and Yule, 2009).

ii. A soil water balance can be used to estimate soil water content in MZs without soil water sensors (Barker et al., 2018).

Many researchers and industry members working to facilitate the implementation of VRI technology are integrating information from soil texture type or soil water sensors (Hedley and Yule, 2009; Lo et al., 2017; Yang et al., 2017) and plant sensing feedback (Stone et al., 2016; O'Shaughnessy et al., 2015; Andrade et al., 2016) or a combination thereof (Andrade et al., 2017; Liakos, 2017; Barker et al., 2018) for decision support. A summary of some of the different sensor systems and approaches that have been tried for VRI irrigation management are listed in table 3.

5. Develop a GIS-based software that stores geospatial data and presents information to the producer in a timely and integrated manner.

6. Investigate approaches that are economically appropriate and acceptable to a producer (role of the irrigation company and/or crop consultant).

\section{Conclusions}

This article discussed the potential advantages and potential disadvantages of VRI technology, provided current examples of advantages and updated advancements in VRI applications and technology. With the incorporation of sensor feedback, GIS-based databases and software interfaces, the implementation of VRI technology has improved but has not reached widespread use. Variable rate irrigation systems for moving sprinklers have been shown to increase crop water productivity and reduce energy demand. These systems have the potential to be effective tools for achieving integrated water management to minimize water wastage, environmental degradation, and provide decision support for irrigation scheduling, while considering spatial and temporal variability in crop water needs. Producers who are considering investment in VRI technology should carefully consider the costs and potential advantages and potential disadvantages to determine whether VRI is a worthwhile choice. Although VRI adoption has been slower than anticipated during its first decade of being commercially available, it is anticipated that VRI adoption will increase in the future. Its adoption will help mitigate limited water supplies, increase compliance with environmental regulations and reduce uncertainty of irrigation demands as affected by short- and long-term climatic variability. Industry members, researchers and extension agents must take the time to document tangible benefits, focus on best management practices, and educate dealers and consultants to help end users implement VRI technology.

\section{ACKNOWLEDGEMENTS}

The authors gratefully acknowledge funding from the Ogallala Aquifer Program, a consortium between USDAAgricultural Research Service, Kansas State University, Texas AgriLife Extension Service \& Research, Texas Tech University, and West Texas A\&M University and is based upon work that is supported by the National Institute of Food and Agriculture, U.S. Department of Agriculture, under award number 2016-67021-24420.

Table 2. Fundamental irrigation management approaches.

\begin{tabular}{|c|c|}
\hline Fundamentals of Irrigation Management: & Results of Disparity: \\
\hline Avoid irrigation of non-arable areas. & Water wastage, regulatory violations \\
\hline $\begin{array}{l}\text { Match the irrigation rate and depth with the soil infiltration rate within a } \\
\text { management zone. }\end{array}$ & $\begin{array}{l}\text { Excessive rate - can lead to runoff, soil erosion, deep percolation } \\
\text { Inadequate rate - can cause yield loss }\end{array}$ \\
\hline Apply smaller amounts of water to sandier soils more frequently. & $\begin{array}{l}\text { Large amounts of water applied will tend to percolate quickly through the } \\
\text { profile and leach nutrients to the groundwater, while small amounts of } \\
\text { water applied infrequently can cause those areas to fall behind in water } \\
\text { storage levels. }\end{array}$ \\
\hline $\begin{array}{l}\text { Apply less water to steep slopes. } \\
\text { Modify tillage method or row orientation to help increase soil water infiltra- } \\
\text { tion rate and prevent runoff }\end{array}$ & $\begin{array}{l}\text { Runoff and possibly erosion from slopes will occur, while in low-lying } \\
\text { areas, runon and ponding will become an issue. Conversely, applying less } \\
\text { water may compromise crop yield. } \\
\text { The concentration of soluble nutrients in surface runoff are higher with } \\
\text { conservation tillage. }{ }^{\text {a] }} \text { Row orientation may adversely affect application } \\
\text { uniformity. }{ }^{[\mathrm{b}]}\end{array}$ \\
\hline
\end{tabular}

[a] Zhao et al., 2001 .

[b] Lamm, 1998. 
Table 3. Sensors and/or general algorithms for variable rate irrigation management.

\begin{tabular}{|c|c|c|c|}
\hline Sensor Type(s) & Deployment Strategy & Irrigation Strategy $^{[\mathrm{a}]}$ & Information Resource \\
\hline None & Static seasonal prescription map. & $\begin{array}{l}\text { Year 1: Reduce irrigations in MZs with high WHC } \\
\text { and increase irrigation in areas with low WHC fol- } \\
\text { lowing uniform preplant irrigations. Year 2: MZs } \\
\text { were based on soil texture using EC survey }\end{array}$ & Bordovsky et al., 1992 \\
\hline
\end{tabular}

\begin{tabular}{lll}
\hline Canopy temperature & $\begin{array}{l}\text { Two in each sprinkler management zone, lo- } \\
\text { cated at the borders of these zones, pointed } \\
\text { sensors }\end{array}$ & $\begin{array}{l}\text { A thermal stress index threshold was established } \\
\text { for each irrigation treatment level. Irrigation } \\
\text { angle towards the crop. Prescription maps }\end{array}$ \\
& $\begin{array}{l}\text { are dynamic. } \\
\text { are dounts of mean peak daily water use X frequency } \\
\text { of days for center pivot sprinkler to make a full ro- } \\
\text { tation were applied. }\end{array}$
\end{tabular}
\begin{tabular}{lll}
\hline $\begin{array}{l}\text { Active spectral radiom- } \\
\text { eter with GPS }\end{array}$ & $\begin{array}{l}\text { Active radiometer was mounted onto a trac- } \\
\text { tor. Passes were completed periodically }\end{array}$ & $\begin{array}{l}\text { NDVI was calculated and converted to crop coeffi- } \\
\text { cient values and used in soil water balance to initi- }\end{array}$
\end{tabular} throughout the growing season. ate irrigations

High density of soil Each probe contains three sensors in each moisture probes (Water- type of $\mathrm{MZ}$ and a web-based user interface. mark) Prescription maps are dynamic.

Estimates matric soil water deficit in the root zone Liakos et al., 2017

to build dynamic prescription maps. Irrigation amounts were based on characteristics of shallow or deep-rooted crops and on immature or mature crops.

Soil water sensors $\quad$ MZs of 100,80 and $60 \%$ of ET were delineated. A static prescription map was used. Two soil water sensing stations containing three sensors each were installed in each of the $100 \% \mathrm{MZs}$.

Spectral and Thermal Plants are used as indicators of soil water Imagery using Manned availability or used to parameterize evapoand Unmanned Aerial Vehicles transpiration requirements

LANDSAT 7 and $8 \quad$ Utilize images as frequently as possible imageries, weather data
Irrigation amounts of $25.4 \mathrm{~mm}$ were applied when soil water content was less than $74 \%$ of FC to the $100 \%$ treatment plots and 80 and $60 \%$ of $25.4 \mathrm{~mm}$ was applied to the $80 \%$ and $60 \% \mathrm{MZs}$, respectively.

[a] MZ- management zone.

FC- field capacity.

\section{REFERENCES}

Abts, K., \& Emanuel, N. (2014). Method of controlling the irrigation of a field with a center pivot irrigation system. U.S. Patent No. 2014/8,849,468 B2.

Adamchuk, V. I., Hummel, J. W., Morgan, M. T., \& Upadhyaya, S. K. (2004). On-the-go soil sensors for precision agriculture. Comput. Electron. Agric., 44(1), 71-91. https://doi.org/10.1016/j.compag.2004.03.002

Adusumilli, N., \& Wang, H. (2018). Analysis of soil management and water conservation practices adoption among crop and pasture farmers in humid-south of the United States. Int. Soil Water Conservation Res., 6(2), 79-86. https://doi.org/10.1016/j.iswcr.2017.12.005

Allaire, S. E., Cambouris, A. N., Lafond, J. A., Lange, S. F., Pelletier, B., \& Dutilleul, P. (2014). Spatial variability of potato tuber yield and plant nitrogen uptake related to soil properties. Agron. J., 106(3), 851-859. https://doi.org/10.2134/agronj13.0468

Almas, L. K., Amosson, S. H., Marek, T. H., \& Colette, W. A. (2003). Economic feasibility of precision irrigation in the Northern Texas High Plains. Proc. Southern Agricultural Economics Assoc.

Andrade, M. A., Evett, S. R., \& O'Shaughnessy, S. A. (2018). Machine learning algorithms applied to the forecasting of crop water stress indicators. Proc. In Tech. Irrigation Show. Irrig. Assoc.

Andrade, M. A., O’Shaughnessy, S. A., \& Evett, S. R. (2015). ARSmartPivot v.1 - Sensor based management software for center pivot irrigation systems. ASABE Paper No. 152170793. St. Joseph, MI: ASABE. https://doi.org/10.13031/aim.20162461449

Andrade, M. A., O'Shaughnessy, S. A., \& Evett, S. R. (2016). A GIS-based decision support tool for center pivot irrigation systems. ASABE Paper No. 162461449. St. Joseph, MI: ASABE. https://doi.org/10.13031/aim.20162461449

Andrade, M. A., O'Shaughnessy, S. A., \& Evett, S. R. (2017). ARSPivot, A sensor based decision support tool for the integrated irrigation management of VRI center pivot systems for center pivot irrigation systems. Proc. 28th Annual Central Plains Irrigation Conf. St. Joseph, MI: ASABE.

Barker, J. B., Franz, T. E., Heeren, D. M., Neale, C. M., \& Luck, J. D. (2017). Soil water content monitoring for irrigation management: A geostatistical analysis. Agric. Water Manag., 188, 36-49. https://doi.org/10.1016/j.agwat.2017.03.024

Barker, J. B., Heeren, D. M., Neale, C. M. U., \& Rudnick, D. R. (2018). Evaluation of variable rate irrigation using a remotesensing-based model. Agric. Water Manag., 203, 63-74. https://doi.org/10.1016/j.agwat.2018.02.022

Baumgart-Getz, A., Prokopy, L. S., \& Floress, K. (2012). Why farmers adopt best management practice in the United States: A meta-analysis of the adoption literature. J. Environ. Manag., 96(1), 17-25. https://doi.org/10.1016/j.jenvman.2011.10.006

Bellvert, J., Marsal, J., Mata, M., \& Girona, J. (2012). Identifying irrigation zones across a 7.5-ha 'Pinot noir' vineyard based on the variability of vine water status and multispectral images. Irrig. Sci., 30, 499-509. https://doi.org/10.1007/s00271-0120380-y

Bolan, N. S., Laurenson, S., Luo, J., \& Sukias, J. (2009). Integrated treatment of farm effluents in New Zealand's dairy operations. Bioresour. Technol., 100(22), 5490-5497. https://doi.org/10.1016/j.biortech.2009.03.004 
Bordovsky, J. P., Lyle, W. M., Lascano, R. J., \& Upchurch, D. R. (1992). Cotton irrigation management with LEPA systems. Trans. ASAE, 35(3), 879-884. https://doi.org/10.13031/2013.28673

Brar, D., Kranz, W. L., Lo, T. H., Irmak, S., \& Martin, D. L. (2017). Energy conservation using variable-frequency drives for centerpivot irrigation: Standard systems. Trans. ASABE, 60(1), 95106. https://doi.org/10.13031/trans.11683

Brevik, E. C., Fenton, T. E., \& Lazari, A. (2006). Soil electrical conductivity as a function of soil water content and implications for soil mapping. Prec. Agric., 7(6), 393-404. https://doi.org/10.1007/s11119-006-9021-x

Cahn, M. D., \& Johnson, L. F. (2017). New approaches to irrigation scheduling of vegetables. Horticulturae, 3(2), 28. https://doi.org/10.3390/horticulturae3020028

Camilli, A., Cugnasca, C. E., Saraiva, A. M., Hirakawa, A. R., \& Correa, P. L. P. (2007). From wireless sensors to field mapping: Anatomy of an application for precision agriculture. Comput. Electron. Agric., 58(1), 25-36. https://doi.org/10.1016/j.compag.2007.01.019

Chavez, J. L., Pierce, F., Elliott, T. V., Evans, R. G., Kim, Y., \& Iversen, W. M. (2010). A remote irrigation monitoring and control system (RIMCS) for continuous move systems. Part B: Field testing and results. Prec. Agric., 11(1), 11-26. https://doi.org/10.1007/s11119-009-9110-8

CMDC Potato Report. (2016). CMDC-Canada-Manitoba Crop Diversification Centre. Retrieved from https://www.gov.mb.ca/agriculture/innovation-andresearch/diversification-centres/pubs/mhpec-annual-report.pdf

Cohen, Y., Alchanatis, V., Saranga, Y., Rosenberg, O., Sela, E., \& Bosak, A. (2017). Mapping water status based on aerial thermal imagery: Comparison of methodologies for upscaling from a single leaf to commercial fields. Prec. Agric., 18, 801-822. https://doi.org/10.1007/s11119-016-9484-3

Cohen, Y., Alchanatis, V., Sela, E., Cohen, S., Meron, M., Bosak, A., \& Brikman, R. (2015). Crop water status estimation using thermography: Multi-year model development using groundbased thermal images. Prec. Agric., 16, 311-329. https://doi.org/10.1007/s11119-014-9378-1

Daccache, A., Knox, J. W., Weatherhead, E. K., Daneshkhah, A., \& Hess, T. M. (2015). Implementing precision irrigation in a humid climate: Recent experiences and on-going challenges. Agric. Water Manag., 147, 135-143. https://doi.org/10.1016/j.agwat.2014.05.018

Davenport, J. R., \& Hattendorf, M. J. (2000). Using site-specific approaches to advance potato management in irrigated systems. Hortechnol., 10(3), 452-457. https://doi.org/10.21273/horttech.10.3.452

de Lara, A., Khosla, R., \& Longchamps, L. (2017). Characterizing spatial variability in soil water content for precision irrigation management. Adv. Animal Biosci., 8(2), 418-422. https://doi.org/10.1017/S2040470017000279

Dennis, S. J., Dynes, R. A., Hedley, C. B., White, T. A., Yule, I. J., \& Snow V., O. (2010). Spatial mapping of soil water holding capacity improves irrigation efficiency. Proc. 4th Australian Dairy Science Symp., (pp. 230-232).

Dukes, M. D., \& Perry, C. (2006). Uniformity testing of variablerate center pivot irrigation control systems. Prec. Agric., 7, 205218. https://doi.org/10.1007/s11119-006-9020-y

Evans, R. G., LaRue, J., Stone, K. C., \& King, B. A. (2013). Adoption of site-specific variable rate irrigation systems. Irri. Sci., 31, 871-887. https://doi.org/10.1007/s00271-012-0365-x

Evett, S. R., Colaizzi, P. D., Schwartz, R. C., \& O’Shaughnessy, S. A. (2014a). Soil water sensing - Focus on variable rate irrigation. Proc. 26th Annual Central Plains Irrigation Conf.
Evett, S. R., O'Shaughnessy, S. A., \& Peters, T. R. (2014b). Irrigation scheduling and supervisory control and data acquisition system for moving and static irrigation systems. U.S. Patent No. 13/403,091.

Evett, S. R., Schwartz, R. C., Mazahrih, N. Th., Jitan, M. A., \& Shaqir, I. M. (2011). Soil water sensors for irrigation scheduling: Can they deliver a management allowed depletion? ActaHortic., 888, 231-237. https://doi.org/10.17660/ActaHortic.2011.888.26

Finkenbiner, C. E., Franz, T. E., Gibson, J., Heeren, D. M., \& Luck, J. D. (2018). Integration of hydrogeophysical datasets for improved water resource management in irrigated systems. Prec. Agric., 20(1), 78-100. https://doi.org/10.1007/s11119-018-9582-5

Floress, K., Garcia de Jalon, S., Church, S. P., Babin, N., UlrichSchad, J. D., \& Prokopy, L. S. (2017). Toward a theory of farmer conservation attitudes: Dual interests and willingness to take action to protect water quality. J. Environ. Psychol., 53, 7380. https://doi.org/10.1016/j.jenvp.2017.06.009

Gili, A., Alvarez, C., Bagnato, R., \& Noellemeyer, E. (2017). Comparison of three methods for delineating management zones for site-specific crop management. Comput. Electron. Agric., 139, 213-223. https://doi.org/10.1016/j.compag.2017.05.022

Gonzalez Perea, R., Daccache, A., Rodriguez Diaz, J. A., Poyato, C. E., \& Knox, J. W. (2018a). Modelling impacts of precision irrigation on crop yield and in-field water management. Prec. Agric., 19, 497-512. https://doi.org/10.1007/s11119-017-9535-4

Gonzalez Perea, R., Poyato, C. E., Montesinos, P., \& Rodriguez Diaz, J. A. (2018b). Prediction of applied irrigation depths at farm level using artificial intelligence techniques. Agric. Water Manag., 206, 229-240.

https://doi.org/10.1016/j.agwat.2018.05.019

Greiner, R., \& Gregg, D. (2011). Farmers' intrinsic motivations, barriers to the adoption of conservation practices and effectiveness of policy instruments: Empirical evidence from northern Australia. Land Use Policy, 28(1), 257-265. https://doi.org/10.1016/j.landusepol.2010.06.006

Gu, J., Yin, G., Huang, P., Guo, J., \& Chen, L. (2017). An improved back propagation neural network prediction model for subsurface drip irrigation system. Comput. Electr. Eng., 60, 5865. https://doi.org/10.1016/j.compeleceng.2017.02.016

Haghverdi, A., Leib, B. G., Washington-Allen, R. A., Ayers, P. D., \& Buschermohle, M. J. (2015). Perspectives on delineating management zones for variable rate irrigation. Comput. Electron. Agric., 117, 154-167. https://doi.org/10.1016/j.compag.2015.06.019

Haghverdi, A., Leib, B. G., Washington-Allen, R. A., Buschermohle, M. J., \& Ayers, P. D. (2016). Studying uniform and variable rate center pivot irrigation strategies with the aid of site-specific water production functions. Comput. Electron. Agric., 123, 327-340. https://doi.org/10.1016/j.compag.2016.03.010

Han, Y. J., Khalilian, A., Owino, T. O., Farahani, H. J., \& Moore, S. (2009). Development of Clemson variable-rate lateral irrigation system. Comput. Electron. Agric., 68(1), 108-113. https://doi.org/10.1016/j.compag.2009.05.002

Hawkins, E., Fulton, J., \& Port, K. (2017). Using soil electrical conductivity (EC) to delineate field variation. Agric. Natural Resour. Retrieved from https://ohioline.osu.edu/factsheet/fabe565

Hedley, C. B. (2015). The role of precision agriculture for improved nutrient management on farms. J. Sci. Food Agric., 95(1), 12-19. https://doi.org/10.1002/jsfa.6734

Hedley, C. B., \& Yule, I. J. (2009). A method for spatial prediction of daily soil water status for precise irrigation scheduling. Agric. Water Manag., 96(12), 1737-1745. https://doi.org/10.1016/j.agwat.2009.07.009 
Hedley, C. B., Yule, I. J., Tuohy, M. P., \& Vogeler, I. (2009). Key performance indicators for simulated variable-rate irrigation of variable soils in humid regions. Trans. ASABE, 52(5), 15751584. https://doi.org/10.13031/2013.29146

Heeren, D. M., Barker, J. B., Lo, T. H., Melvin, S. R., Martin, D. L., \& Luck, J. D. (2017). Considerations in adopting variable rate irrigation. Retrieved from

https://water.unl.edu/article/agriculturalirrigation/considerations-adopting-variable-rate-irrigation

Henry, C. G., Merritt McDougall, W., Allen, C. D., Reba, M. L., \& Carman, D. K. (2014). Can variable frequency drives reduce irrigation costs for rice producers? ASABE Paper No. 141928170. St. Joseph, MI: ASABE. https://doi.org/10.13031/aim.20141928170

Hoffmann, H., Jensen, R., Thomsen, A., Nieto, H., Rasmussen, J., \& Friborg, T. (2016). Crop water stress maps for an entire growing season from visible and thermal UAV imagery. Biogeosci., 13, 6545-6563. https://doi.org/10.5194/bg-13-65452016

Howell, T. A. (2002). Irrigation efficiency. In Encyclopedia of soil science (pp. 736-741). New York, NY: Marcel Dekker.

Kargas, G., \& Soulis, K. X. (2019). Performance evaluation of a recently developed soil water content, dielectric permittivity, and bulk electrical conductivity electromagnetic sensor. Agric. Water Manag., 213, 568-579. https://doi.org/10.1016/j.agwat.2018.11.002

Khosla, R., Inman, D., Westfall, D. G., Reich, R. M., Frasier, M., Mzuku, M.,... Hornung, A. (2008). A synthesis of multidisciplinary research in precision agriculture: Site-specific management zones in the semi-arid western Great Plains of the USA. Prec. Agric., 9, 85-100. https://doi.org/10.1007/s11119008-9057-1

Khot, L. R., Sankaran, S., Carter, A. H., Johnson, D. A., \& Cummings, T. F. (2016). UAS imaging-based decision tools for arid winter wheat and irrigated potato production management. Int. J. Remote Sensing, 37(1), 125-137. https://doi.org/10.1080/01431161.2015.1117685

Kim, D.-W., Yun, H. S., Jeong, S.-J., Kwon, Y.-S., Kim, S.-G., Lee, W. S., \& Kim, H.-J. (2018). Modeling and testing of growth status for Chinese cabbage and white radish with UAV-based RGB imagery. Remote Sensing, 10(4), 563. https://doi.org/10.3390/rs10040563

Kim, Y., \& Evans, R. G. (2009). Software design for wireless sensor-based site-specific irrigation. Comput. Electron. Agric., 66(2), 159-165. https://doi.org/10.1016/j.compag.2009.01.007

King, B. A., Wall, R. W., \& Karsky, T. F. (2009). Center-pivot irrigation system for independent site-specific management of water and chemical application. Appl. Eng. Agric., 25(2), 187198. https://doi.org/10.13031/2013.26334

King, B. A., Wall, R. W., Kincaid, D. C., \& Westermann, D. T. (2005). Field testing of a variable rate sprinkler and control system for site-specific water and nutrient application. Appl. Eng. Agric., 21(5), 847-853. https://doi.org/10.13031/2013.19712

Kranz, W. L., Evans, R. G., Lamm, F. R., O’Shaughnessy, S. A., \& Peters, R. T. (2012a). A review of mechanical move sprinkler irrigation control and automation technologies. Appl. Eng. Agric., 28(3), 389-397. https://doi.org/10.13031/2013.41494

Kranz, W., Glaser, R., Ross, G., \& Rogers, D. H. (2012b). Center pivot sprinkler nozzle replacement and maintenance. Proc. 24th Annual Central Plains Irrigation Conf. CPIA.

Lamm, F. R. (1998). Uniformity of in-canopy center pivot sprinkler irrigation. ASAE Paper No. 982069. St. Joseph, MI: ASAE.
Lamm, F. R., \& Rogers, D. H. (2015). The importance of irrigation scheduling for marginal capacity systems growing corn. Appl. Eng. Agric., 31(2), 261-265.

https://doi.org/10.13031/aea.31.10966

LaRue, J. (2014). Management considerations for variable rate irrigation. Proc. 26th Annual Central Plains Irrigation Conf. CPIA.

LaRue, J. (2018). System and method for irrigation management using machine learning workflows. U.S. Patent No. 2018/ 0348714, A1.

LaRue, J., \& Evans, R. G. (2012). Considerations for variable rate irrigation. Proc. 24th Annual Central Plains Irrigation Conf. CPIA.

Levidow, L., Zaccaria, D., Maia, R., Vivas, E., Todorovic, M., \& Scardigno, A. (2014). Improving water-efficient irrigation: Prospects and difficulties of innovative practices. Agric. Water Manag., 146, 84-94. https://doi.org/10.1016/j.agwat.2014.07.012

Li, X., Zhao, W., Li, J., \& Li, Y. (2018). Crop yield and water use efficiency as affected by different soil-based management methods for variable-rate irrigation in a semi-humid climate. Trans. ASABE, 61(6), 1915-1922. https://doi.org/10.13031/trans.13036

Liakos, V., Porter, W., Liang, X., Tucker, M. A., McLendon, A., \& Vellidis, G. (2017). Dynamic variable rate irrigation: A tool for greatly improving water use efficiency. Adv. Animal Biosci., 8(2), 557-563. https://doi.org/10.1017/S2040470017000711

Liu, Z., Grabow, G. L., Huffman, R. L., Osborne, J., \& Evans, R. O. (2012). Factors affecting uniformity of irrigation-type manure application systems. Appl. Eng. Agric., 28(1), 43-56. https://doi.org/10.13031/2013.41285

Lo, T. H. (2015). Quantification of variable rate irrigation benefits and spatial variability in root zone water holding capacity. MS thesis. Lincoln: University of Nebraska-Lincoln, Department of Biological Systems Engineering.

Lo, T. H., M. Heeren, D., Martin, D. L., Mateos, L., Luck, J. D., \& Eisenhauer, D. (2016). Pumpage reduction by using variablerate irrigation to mine undepleted soil water. Trans. $A S A B E$, 59(5), 1285-1298. https://doi.org/10.13031/trans.59.11773

Lo, T. H., Heeren, D. M., Mateos, L., Luck, J. D., Martin, D. L., Miller, K. A.,... Shaver, T. M. (2017). Field characterization of field capacity and root zone available water capacity for variable rate irrigation. Appl. Eng. Agric., 33(4), 559-572. https://doi.org/10.13031/aea.11963

Longchamps, L., Khosla, R., Reich, R., \& Gui, D. W. (2015). Spatial and temporal variability of soil water content in leveled fields. SSSAJ, 79(5), 1446-1454. https://doi.org/10.2136/sssaj2015.03.0098

Maestrini, B., \& Basso, B. (2018a). Drivers of within-field spatial and temporal variability of crop yield across the US Midwest. Sci. Rep., 8(1), 14833. https://doi.org/10.1038/s41598-01832779-3

Maestrini, B., \& Basso, B. (2018b). Predicting spatial patterns of within-field crop yield variability. Field Crops Res., 219, 106112. https://doi.org/10.1016/j.fcr.2018.01.028

Marek, T., Almas, L., Amosson, S., \& Cox, E. (2001). The feasibility of variable rate irrigation with center pivot systems in the northern Texas High Plains. ASABE Paper No. 011117. St. Joseph, MI: ASAE. https://doi.org/10.13031/2013.3443

Martin, C. A., Burr, C., \& Olson, B. (2015). Irrigation handbook for the Great Plains. Gothenburg, NE: Monsanto Water Utilization Learning Center. Retrieved from https://monsanto.com/app/uploads/2017/06/irrigation-handbookfor-the-great-plains.pdf 
McCarthy, A. C., \& Hancock, N. H. (2013). Advanced process control of irrigation: The current state and an analysis to aid future development. Irrig. Sci., 31, 183-192. https://doi.org/10.1007/s00271-011-0313-1

McCarthy, A. C., Hancock, N. H., \& Raine, S. R. (2010). VARIwise: A general-purpose adaptive control simulation framework for spatially and temporally varied irrigation at subfield scale. Comput. Electron. Agric., 70(1), 117-128. https://doi.org/10.1016/j.compag.2009.09.011

McCarthy, A. C., Hancock, N. H., \& Raine, S. R. (2014). Simulation of irrigation control strategies for cotton using Model Predictive Control within the VARIwise simulation framework. Comput. Electron. Agric., 101, 135-147. https://doi.org/10.1016/j.compag.2013.12.004

McDowell, R. W. (2017). Does variable rate irrigation decrease nutrient leaching losses from grazed dairy farming? Soil Use Manag., 33(4), 530-537. https://doi.org/10.1111/sum.12363

McDowell, R. W., van der Weerden, T. J., \& Campbell, J. (2011). Nutrient losses associated with irrigation, intensification and management of land use: A study of large scale irrigation in North Otago, New Zealand. Agric. Water Manag., 98(5), 877885. https://doi.org/10.1016/j.agwat.2010.12.014

Migliaccio, K. W., Morgan, K. T., Vellidis, G., Zotarelli, L., Fraisse, C., Zurweller, B. A.,... Rowland, D. L. (2016). Smartphone apps for irrigation scheduling. Trans. ASABE, 59(1), 291-301. https://doi.org/10.13031/trans.59.11158

Miller, K. A., Luck, J. D., Heeren, D. M., Lo, T., Martin, D. L., \& Barker, J. B. (2018). A geospatial variable rate irrigation control scenario evaluation methodology based on mining root zone available water capacity. Prec. Agric., 19(4), 666-683. https://doi.org/10.1007/s11119-017-9548-z

Miller, N. J., Griffin, T. W., Bergtold, J., Ciampitti, I. A., \& Sharda, A. (2017). Farmer's adoption path of precision agriculture technology. Adv. Animal Biosci., 8(2), 708-712. https://doi.org/10.1017/S2040470017000528

Milton, A. W., Perry, C. D., \& Khalilian, A. (2006). Status of variable-rate irrigation in the Southeast. ASABE Paper No. 061075. St. Joseph, MI: ASABE.

Moral, F. J., Terron, J. M., \& Silva, J. R. (2010). Delineation of management zones using mobile measurements of soil apparent electrical conductivity and multivariate geostatistical techniques. Soil Tillage Res., 106(2), 335-343. https://doi.org/10.1016/j.still.2009.12.002

Omary, M., R. Camp, C., \& J. Sadler, E. (1997). Center pivot irrigation system modification to provide variable water application depths. Appl. Eng. Agric., 13(2), 235-239. https://doi.org/10.13031/2013.21604

Or, D., \& Wrath, J. M. (2002). Soil water content and water potential relationships. In A. Warrick (Ed.), Soil physics companion. Danvers, MA: CRC Press.

O'Shaughnessy, S. A., \& Evett, S. R. (2010a). Canopy temperature based system effectively schedules and controls center pivot irrigation of cotton. Agric. Water Manag., 97(9), 1310-1316. https://doi.org/10.1016/j.agwat.2010.03.012

O'Shaughnessy, S. A., \& Evett, S. R. (2010b). Developing wireless sensor networks for monitoring crop canopy temperature using a moving sprinkler system as a platform. Appl. Eng. Agric., 26(2), 331-341. https://doi.org/10.13031/2013.29534

O’Shaughnessy, S. A., Andrade, M. A., Stone, K. C., Vories, E. D., Sui, R., \& Evett, S. R. (2018). Adapting a VRI irrigation scheduling system for different climates. Proc. In Techn. Irrigation Show. Irrig. Assoc.

O’Shaughnessy, S. A., Evett, S. R., \& Colaizzi, P. D. (2015). Dynamic prescription maps for site-specific variable rate irrigation of cotton. Agric. Water Manag., 159, 123-138. https://doi.org/10.1016/j.agwat.2015.06.001
O’Shaughnessy, S. A., Evett, S. R., Colaizzi, P. D., \& Howell, T. A. (2012). Grain sorghum response to irrigation scheduling with the time-temperature threshold method and deficit irrigation levels. Trans. ASABE, 55(2), 451-461. https://doi.org/10.13031/2013.41395

O’Shaughnessy, S. A., Urrego, Y. F., Evett, S. R., Colaizzi, P. D., \& Howell, T. A. (2013). Assessing application uniformity of a variable rate irrigation system in a windy location. Appl. Eng. Agric., 29(4), 497-510.

https://doi.org/http://dx.doi.org/10.13031/aea.29.9931

Padhi, J., Misra, R. K., \& Payero, J. O. (2012). Estimation of soil water deficit in an irrigated cotton field with infrared thermography. Field Crops Res., 126, 45-55. https://doi.org/10.1016/j.fcr.2011.09.015

Perry, C., \& Pocknee, S. (2003). Precision pivot irrigation controls to optimize water application. Proc. In Tech. Irrigation Show. Irrig. Assoc.

Peters, R. T., \& Flury, M. (2017). Variable rate irrigation on center pivots. What is it? Should I invest? Proc. Western Alfalfa \& Forage Symp. Producing Quality Forages in the West. UC California: Alfalfa \& Forage Systems Workgroup \& Cooperative Extension Services.

Peters, R. T., Desta, K., \& Nelson, L. (2013). Practical use of soil moisture sensors and their data for irrigation scheduling. Washington State University Ext. Fact Sheet FS083E. Retrieved from https://cru.cahe.wsu.edu/CEPublications/FS083E/FS083E.pdf

Pierce, F. J., Chavez, J. L., Elliott, T. V., Matthews, G. R., Evans, R. G., \& Kim, Y. (2006). A remote real-time continuous move irrigation control and monitoring system. ASABE Paper No. 062162. St. Joseph, MI: ASABE.

Pierpaoli, E., Carli, G., Pignatti, E., \& Canavari, M. (2013). Drivers of precision agriculture technologies adoption: A literature review. Procedia Technol., 8, 61-69. https://doi.org/10.1016/j.protcy.2013.11.010

Pokhrel, B. K., Paudel, K. P., \& Segarra, E. (2018). Factors affecting the choice, intensity, and allocation of irrigation technologies by U.S. cotton farmers. Water, 10(6), 706. https://doi.org/10.3390/w10060706

Price, J. A., Workneh, F., Evett, S. R., Jones, D. C., Arthur, J., \& Rush, C. M. (2010). Effects of wheat streak mosaic virus on root development and water-use efficiency of hard red winter wheat. Plant Disease, 94(6), 766-770. https://doi.org/10.1094/pdis-946-0766

Quebrajo, L., Perez-Ruiz, M., Perez-Urrestarazu, L., Martinez, G., \& Egea, G. (2018). Linking thermal imaging and soil remote sensing to enhance irrigation management of sugar beet. Biosyst. Eng., 165, 77-87. https://doi.org/10.1016/j.biosystemseng.2017.08.013

Rhoades, J. D., Kandiah, A., \& Mashali. A., M. (1992). The use of saline waters for crop production. FAO Irrigation and Drainage Paper No. 48. Rome, Italy: United Nations FAO. Retrieved from https://www.fao.org/3/a-t0667e.pdf

Rogers, D. H. (2012). Efficient crop water use in Kansas, Ch. 3: Evaluating center pivot nozzle package performance. Kansas State Research and Ext. MF-3066. 9-17.

Sadler, E. J., Evans, R. G., Stone K., C., \& Camp, C. R. (2005). Opportunities for conservation with precision irrigation. JSWC, 60(6), 371-379.

Schaible, G. D., \& Aillery, M. P. (2012). Water Conservation in irrigated agriculture: Trends and challenges in the face of emerging demand. Economic Information Bull. No. 99. Washington, DC: USDA. https://doi.org/10.2139/ssrn.2186555 
Schaible, G. D., \& Aillery, M. P. (2017). Chapter 2.1.1 - Challenges for U.S. irrigated agriculture in the face of emerging demands and climate change. In J. R. Ziolkowska, \& J. M. Peterson (Eds.), Competition for water resources (pp. 44-79). https://doi.org/10.1016/B978-0-12-803237-4.00004-5

Schepers, A. R., Shanahan, J. F., Liebig, M. A., Schepers, J. S., Johnson, S. H., \& Luchiari Jr., A. (2004). Appropriateness of management zones for characterizing spatial variability of soil properties and irrigated corn yields across years. Agron. J., 96(1), 195-203. https://doi.org/10.2134/agronj2004.1950

Schimmelpfennig, D. (2016). Farm profits and adoption of precision agriculture, ERR-217, USDA, Economic Research Service Report. Washington, DC: USDA.

Schwartz, R. C., \& Evett, S. R. (2016). Soil water sensors for evaluating crop water status. Proc. 28th Annual Central Plains Irrigation Conf. CPIA.

Schwartz, R., Evett, S., \& Schlegel, A. (2011). Monitoring near surface soil water and associated dynamics of infiltration and evaporation fluxes. European Geophysical Union General Assembly. Abstracts, 13, EGU2011-1990. Vienna, Austria.

Sigua, G. C., Stone, K. C., Bauer, P. J., Szogi, A. A., \& Shumaker, P. D. (2017). Impacts of irrigation scheduling on pore water nitrate and phosphate in coastal plain region of the United States. Agric. Water Manag., 186, 75-85. https://doi.org/10.1016/j.agwat.2017.02.016

Smith, A. K. (2012). Matching application to the varying speed and geometry of center pivot swing arm corner systems. ASABE Paper No. 121336824. St. Joseph, MI: ASABE. https://doi.org/10.13031/2013.41706

Smith, R. J., Baillie, J. N., McCarthy, A. C., Raine, S. R., \& Baillie, C. P. (2010). Review of precision irrigation technologies and their application. National Centre for Eng. Agric. Publ. 1003017/1. Toowoomba: USQ.

Stone, K. C., \& Sadler, E. J. (2016). Assessing spatial variation of corn response to irrigation using a bayesian semiparametric model. Trans. ASABE, 59(1), 251-261. https://doi.org/10.13031/trans.59.10942

Stone, K. C., Bauer, P. J., \& Sigua, G. C. (2016). Irrigation management using an expert system, soil water potentials, and vegetative indices for spatial applications. Trans. ASABE, 59(3), 941-948. https://doi.org/10.13031/trans.59.11550

Sudduth, K. A., Drummond, S. T., \& Kitchen, N. R. (2001). Accuracy issues in electromagnetic induction sensing of soil electrical conductivity for precision agriculture. Comput. Electron. Agric., 31(3), 239-264. https://doi.org/10.1016/S01681699(00)00185-X

Sui, R., \& Fisher, D. K. (2015). Field test of a center pivot irrigation system. Appl. Eng. Agric., 31(1), 83-88. https://doi.org/10.13031/aea.31.10539

Sui, R., \& Yan, H. (2017). Field study of variable rate irrigation management in humid climates. Irrig. Drain., 66(3), 327-339. https://doi.org/10.1002/ird.2111

Sun, L., Yang, Y., Hu, J., Porter, D., Marek, T., \& Hillyer, C. (2017). Reinforcement learning control for water-efficient agricultural irrigation. Proc. 16th IEEE Int. Conf. Ubiquitous Computing and Communication (pp. 1334-1341). IEEE. https://doi.org/10.1109/ISPA/IUCC.2017.00203

Suwannee River Basin (SWIM) Plan. (2017). ESA/ D150586.00. Suwannee River Basin Surface Water Improvement and Management (SWIM) Plan. Retrieved from http://www.mysuwanneeriver.com/DocumentCenter/View/1202 7

Swaney, D. P., Howarth, R. W., \& Hong, B. (2018). Nitrogen use efficiency and crop production: Patterns of regional variation in the United States, 1987-2012. Sci. Total Environ., 635, 498-511. https://doi.org/10.1016/j.scitotenv.2018.04.027
Texas Water Report. (2014). Going deeper for the solution. Publ. No. 96-1746. Retrieved from https://www.TXWaterReport.org

Tey, Y. S., \& Brindal, M. (2012). Factors influencing the adoption of agricultural technologies: A review for policy implications. Prec. Agric., 13, 713-730. https://doi.org/10.1007/s11119-0129273-6

Trost, B., Prochnow, A., Drastig, K., Meyer-Aurich, A., Ellmer, F., \& Baumecker, M. (2013). Irrigation, soil organic carbon and N2O emissions: A review. Agron. Sustainable Dev., 33(4), 733749. https://doi.org/10.1007/s13593-013-0134-0

USDA-NASS. (2013). 2012 Census of agriculture. 2013 Farm and ranch irrigation survey. Washington, DC: USDA-NASS.

USEPA. (2014). Regulatory Flexibility Act Section 610 Review of the National Pollutant Discharge Elimination System (NPDES) Permit Regulation and Effluent Limitation Guidelines and Standards for Concentrated Animal Feeding Operations (CAFLs). Washington, DC: USEPA. Retrieved from https://www.regulations.gov/document?D=EPA-HQ-OW-20120813-0216

Vellidis, G., Liakos, V., Andreis, J. H., Perry, C. D., Porter, W. M., Barnes, E. M.,... Migliaccio, K. W. (2016). Development and assessment of a smartphone application for irrigation scheduling in cotton. Comput. Electron. Agric., 127, 249-259. https://doi.org/10.1016/j.compag.2016.06.021

Vellidis, G., Tucker, M., Perry, C., Kvien, C., \& Bednarz, C. (2008). A real-time wireless smart sensor array for scheduling irrigation. Comput. Electron. Agric., 61(1), 44-50. https://doi.org/10.1016/j.compag.2007.05.009

Von Bueren, S., Burkart, A., Hueni, A., Rascher, U., Tuohy, M., \& Yule, I. (2014). Comparative validation of UAV based sensors for the use in vegetation monitoring. Biogeosci. Discuss., 11, 3837-3864. https://doi.org/10.5194/bgd-11-3837-2014

Vories, E., Stevens, W., Rhine, M., \& Straatmann, Z. (2017). Investigating irrigation scheduling for rice using variable rate irrigation. Agric. Water Manag., 179, 314-323. https://doi.org/10.1016/j.agwat.2016.05.032

Workneh, F., O'Shaughnessy, S., Evett, S., \& Rush, C. M. (2017). Relationships between early wheat streak mosaic severity levels and grain yield: Implications for management decisions. Plant Disease, 101(9), 1621-1626. https://doi.org/10.1094/pdis-02-170176-re

Yang, C., Everitt, J. H., Murden, D., \& Robinson, J. R. (2002). Spatial variability in yields and profits within ten grain sorghum fields in south Texas. Trans. ASAE, 45(4), 897-906. https://doi.org/10.13031/2013.9936

Yang, Y., Sun, L., Hu, J., Porter, D., Marek, T., \& Hillyer, C. (2017). A reliable soil moisture sensing methodology for agricultural irrigation. Proc. 16th IEEE Int. Conf. Ubiquitous Computing and Communication, (pp. 1342-1349). https://doi.org/10.1109/ISPA/IUCC.2017.00204

Yari, A., Madramootoo, C. A., Woods, S. A., \& Adamchuk, V. I. (2017a). Performance evaluation of constant versus variable rate irrigation. Irrig. Drain., 66(4), 501-509. https://doi.org/10.1002/ird.2131

Yari, A., Madramootoo, C. A., Woods, S. A., Adamchuk, V. I., \& Huang, H.-H. (2017b). Assessment of field spatial and temporal variabilities to delineate site-specific management zones for variable-rate irrigation. J. Irrig. Drain. Eng., 143(9), 04017037. https://doi.org/10.1061/(ASCE)IR.1943-4774.0001222

Younker, B. J. (2018). Variable rate irrigation. Retrieved from https://www.nrcs.usda.gov/wps/portal/nrcs/detail/ks/newsroom/f eatures/?cid=nrcs142p2_033511

Zhang, N., Wang, M., \& Wang, N. (2002). Precision agriculture: A worldwide overview. Comput. Electron. Agric., 36(2), 113-132. https://doi.org/10.1016/S0168-1699(02)00096-0 
Zhao, S. L., Gupta, S. C., Huggins, D. R., \& Moncrief, J. F. (2001). Tillage and nutrient source effects on surface and subsurface water quality at corn planting. $J E Q, 30(3), 998-1008$. https://doi.org/10.2134/jeq2001.303998x

Zhao, W., Li, J., Yang, R., \& Li, Y. (2017). Crop yield and water productivity responses in management zones for variable-rate irrigation based on available soil water holding capacity. Trans ASABE, 60(5), 1659-1667. https://doi.org/10.13031/trans.12340
Zhu, H., Sorensen, R. B., Butts, C. L., Lamb, M. C., \& Blankenship, P. D. (2002). A pressure regulating system for variable irrigation flow controls. Appl. Eng. Agric., 18(5), 533-540. https://doi.org/10.13031/2013.10157 